Recorregut de recerca geològica i mineralògica per les comarques de Gúdar - Javalambre i de l'Alcalatén: des de Mosqueruela a Puertomingalvo, Sant Joan de Penyagolososa i a Vistabella del Maestrat

Josep Maria Mata-Perelló

Joaquim Sanz Balagué

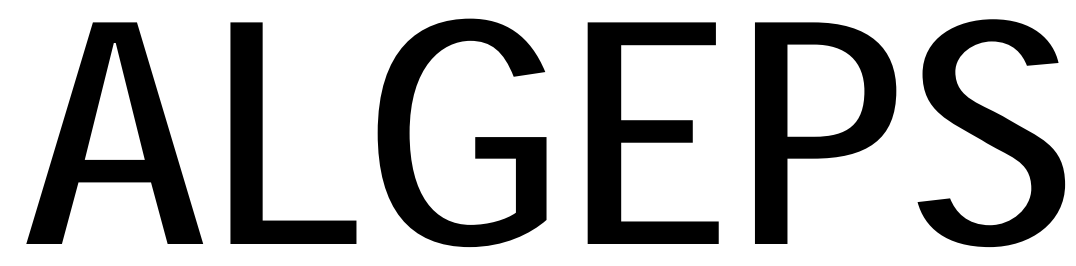

REVISTA DE GEOLOGIA

n. 2

ABRIL 2015 


\title{
RECORREGUT DE RECERCA GEOLÒGICA I MINERALÒGICA PER LES COMARQUES DE GÚDAR - JAVALAMBRE I DE L'ALCALATÉN: DES DE MOSQUERUELA A PUERTOMINGALVO, SANT JOAN DE PENYAGOLOSOSA I A VISTABELLA DEL MAESTRAT
}

\author{
Josep Maria Mata-Perelló \\ Museu de geologia Valentí Masachs, Escola Politècnica Superior d'Enginyeria de Manresa \\ (EPSEM), Universitat Politècnica de Catalunya · BarcelonaTech (UPC), 08272 Manresa, Spain
}

\section{Joaquim Sanz Balagué}

Departament d'Enginyeria Minera i Recursos Naturals (EMRN), Escola Politècnica Superior d'Enginyeria de Manresa (EPSEM), Universitat Politècnica de Catalunya - BarcelonaTech (UPC), 08272 Manresa, Spain

\section{Paraules clau: Patrimoni geològic i miner; Sistema ibèric; País Valencià}

\begin{abstract}
Resum
Itinerari realitzat el dia 6 de desembre del 2014. Aquest itinerari es desenvoluparà íntegrament per una de les unitats geològiques que constitueixen el País Valencià: concretament per la que ocupa la major part de la seva superfície, per la Serralada Ibèrica (i dintre d'aquesta pels sectors denominats Muntanyam de Castelló. També, es podria incloure bona part del recorregut, dintre de la denominada Conca del Maestrat.
\end{abstract}

Així, l'itinerari discorrerà íntegrament per la zona també denominada del Maestrat, pels seus sectors corresponents a la Zona d'Enllaç entre les dues serralades anteriorment esmentades, de direccions: NE-SW (o NNE-SSW) i WNW-ESE (de vegades NW-SE), corresponents a les alineacions catalana $i$ ibèrica, respectivament.

En funció d'aquestes circumstàncies ens trobarem molts indrets amb clares interferències entre les dues direccions acabades d'esmentar; tot $i$ que en aquestes interferències predominarà quasi sempre en aquesta zona, la direcció ibèrica.

Aquest conjunt, es troba constituït majoritàriament per relleus mesozoics (fonamentalment pertanyents al Cretàcic $i$ al Juràssic), de naturalesa calcària, com succeeix al propi cim del Penyagolosa l'indret considerat com al més alt del País Valencià. El recorregut de l'itinerari passarà per dues comarques: la del Gúdar - Javalambre (Teruel) i la de l'Alcalatén (Castelló).

Així, el recorregut començarà a la primera comarca, prop de la població de Mosqueruela, per tal d'anar per la comarca fins arribar prop de la Puertomingalvo. Després es penetrarà a la segona comarca, per la qual es circularà fins a Vistabella del Maestrat, per on finalitzarà el recorregut, després d'haver-nos apropat al Penyagolosa. 


\section{Objectius fonamentals}

Els objectius que es pretenen assolir, en aquest itinerari, es centraran, fonamentalment, en els següents aspectes:

1.- Estudi dels materials dels afloraments mesozoics (de tots els períodes que el constitueixen, $i$ en especial del Cretàcic), que constitueixen el Sistema Ibèric, dintre del sector anomenat "Muntanyam de Castelló" (RIBA, 1976).

2.- Observació de l'estructura del Sistema Ibèric (i més concretament del que es troba situat dintre del sector anomenat anteriorment, (d'acord amb RIBA, 1976), que anirem trobant a bona part del recorregut de l'itinerari.

3.- Reconeixement de les interferències entre les direccions ibèriques (de components fonamentals WNW-ESE i NW-SE, i fins i tot W-E), amb les direccions catalanes (de components NE-SW i NNE-SSW), ja força amorteguides. Unes i altres les trobarem a diferents zones del recorregut, dintre de la denominada Zona d'Enllaç.

4.- Observació de les diverses explotacions, situades al llarg del recorregut de l'itinerari. Entre aquestes, farem esment de les explotacions de "llosses" situades a diferents indrets dels termes de Mosqueruela i de Puertomingalvo. Es localitzen entre els afloraments cretàcics.

5.- Observació dels impactes produïts sobre el Medi Natural, com a conseqüència de les explotacions esmentades a l'apartat anterior; i també, si s'escau de les restauracions dutes a terme.

6.- Observació dels diferents indrets relacionats amb la morfologia kàrstica (fonamentalment dels denominats poljès, uwales i dolines) que els que trobarem prop de Mosqueruela i de Vistabella del Maestrat.

7.- Observació dels indrets relacionats amb el nostre Patrimoni Geològic i Miner (en concret dels diferents Punts d'Interès Geològic o PIG; i dels diferents Punts d'Interès Miner o PIM), que anirem trobant al llarg del present itinerari. Entre els primers, cal parlar dels poljè de Mosqueruela i del poljè de Vistabella del Maestrat, uns dels indrets catalogats dintre del Patrimoni Geològic d’Aragón i de la Comunitat Valenciana, respectivament.

\section{Antecedents}

Pel que fa al recorregut de l'itinerari, existeixen solament tres antecedents relatius als itineraris que discorren per aquests indrets. Aquests antecedents son precisament nostres. Es tracta de: MATA-PERELLÓ $(1995,2002,2003,2014 a$ i 2014b); així com MATA-PERELLÓ i MONTANÉ GARCIA (2004). I també en els treballs de MATA PERELLÓ i VILALTELLA FARRÀS (2005a, 2005b i 2014). En tots els casos es tracta d'uns recorreguts molt semblants al del present itinerari, especialment pel que fa als trams finals del mateix.

Pel que fa a l'estructura geològica de la zona per la qual discorre el recorregut de l'itinerari, ens referirem a dos treballs, sensiblement importants: concretament a GUIMERÀ et altri (1992), i a RIBA et altri (1976). Tots dos fan referència al conjunt dels Països Catalans. També cal referència dels treballs de I'IGME (1972-1977) i IGME (1986), relatius als indrets per on passarà l'itinerari.

Pel que fa a la descripció de les mineralitzacions, es referirem a un altres antecedents bibliogràfic mostres. Concretament dels treballs de: MATA-PERELLÓ (1991); i també del treballs del mateix autor (1992) dedicats al inventari mineralògic de les dues comarques (i de les regions a les que pertanyen), per les quals transitarà el recorregut d'aquest itinerari. 
I, finalment, en relació al Patrimoni Geològic, farem esment del treball aragonès que hem esmentat a l'apartat anterior: DGA (2001).

Tots aquests treballs, i d'altres, apareixeran ressenyats a l'apartat dedicat a la bibliografia.

\section{Recorregut de l'itinerari}

El recorregut de l'itinerari discorrerà íntegrament per dues comarques: una de la Región del Bajo Aragón (la comarca turolense del Gúdar - Javalambre) i una altra de la Regió de Castelló (la de I'Alcalatén). Concretament, el recorregut s'iniciarà a la del comarca de Gúdar Javalambre, prop de Mosqueruela) per a finalitzar a la segona (prop de Vistabella del Maestrat).

Així, el recorregut de l'itinerari s'iniciarà per les immediacions de la població de Mosqueruela (ubicada dintre de la comarca aragonesa del Gúdar - Javalambre, però dintre del Maestrazgo Històric). Pels voltants d'aquesta població, ja s'efectuaran diverses aturades, en torn de la mateixa.

Després, el recorregut es dirigirà cap a ponent (seguint la carretera $A-1701$ ), la qual es dirigeix cap a Linares de Mora). Tot i així, després ens caldrà seguir per la carretera valenciana CV - 175 (la qual es dirigeix cap a Puertomingalvo). En aquest tram, caldrà fer diverses aturades.

Posteriorment, encara dintre de la comarca aragonesa de Gúdar - Javalambre, abans d'arribar a Puertomingalvo, caldrà continuar per la carretera valenciana CV - 170. Per aquesta, anirem cap a Vistabella del Maestrat, després d'entrar a la comarca valenciana del Alcalatén. Tot i així, abans d'arribar a aquesta darrera població, farem dues filloles: una per anar a Sant Joan de Penyagolosa i l'altra per tal d'apropar-nos al "Camp d'Aviació". Després, en arribar a Vistabella, finalitzarà aquest itinerari

\section{Advertiments previs}

Com en altres recorreguts de recerca geològica i mineralògica ..., si es disposa del temps suficient, poden efectuar-se passant per totes les parades i filloles. En cas contrari, recomanem prescindir de les anomenades parades - condicionals.

També cal tenir en conte que una part del recorregut final de l'itinerari, es realitzarà per camins de terra, per la qual cosa caldrà prendre les degudes precaucions,

Cal tenir, com sempre, una cura molt especial de respecte a la natura, al llarg de tot el recorregut de l'itinerari, i també fora d'ell.

\section{Descripció de l'itinerari}

Com sempre, s'estructurarà en una sèrie de parades, que veurem breument a continuació. En cada una de les parades, s'indicarà (entre parèntesi) el número del mapa topogràfic, a escala 1:50.000, on es troba l'aturada.

En aquesta ocasió, les aturades es troben situades dintre dels següents fulls del Mapa Topogràfico a Escala 1:50.000 (editat per I'Instituto Geográfico y Catastral de España): 569 (o de Vilafranca del Cid) i 592 (o de Vilahermosa del Río). 
Així doncs, la relació ordenada de les aturades que constitueixen aquest itinerari és la següent:

\subsection{Parada 1 - condicional. Carretera de Mosqueruela a Linares de Mora, A-1701, sortida de Mosqueruela, (terme municipal de Mosqueruela, comarca de Gúdar - Javalambre). (Full 569).}

El recorregut d'aquest itinerari, el començarem al bell mig de la població de Mosqueruela (una localitat del Maestrazgo Històric, que pertany a la comarca de Gúdar - Javalambre). Així, farem I'aturada a la sortida del poble, anant cap a Puertomingalvo i cap a Linares de Mora.

Aquest indret es troba situat al Sistema Ibèric, dintre de la Cuenca del Maetrazgo. Així, per arreu, es veuen afloraments dels materials mesozoics. Aquests materials són eminentment carbonatats i pertanyen al Cretàcic, concretament al Cenomanià. Així, es fan palesos els nivells de calcàries i de calcàries arenoses. Per d'altra banda, sobre aquests materials hem trobat moltes formacions kàrstiques.

Precisament, en aquest indret es fa pales un interessant poljé. Es tracta d'un graó més del conegut interessant Poljé de Mosqueruela, que anirem veient a les aturades següents d'aquest itinerari. Aquest indret és un LIG (Lloc d'Interès Geològic) d'una gran importància.

\subsection{Parada 2. carretera a Linares de Mora i a Puertomingalvo, km 1 A-1701, (terme municipal de Puertomingalvo, comarca de Gúdar - Javalambre). (Full 592).}

Després de fer l'aturada anterior, cal continuar cap a ponent, cap a Puertomingalvo, anant per la carretera autonòmica aragonesa A-1701. En arribar a les immediacions del $\mathrm{Km} \mathrm{1}$, cal fer una nova aturada, aproximadament a $4 \mathrm{Km}$ de la parada anteriorment realitzada.

En aquest recorregut, hem anat trobant afloraments dels materials mesozoics esmentats a la parada anterior.

En aquest indret hi ha una explotació d'aquests materials carbonatats per tal de dedicar-los per a l'extracció de lloses per a la construcció. Encara es troben a l'actualitat en actiu. (fotografia 1)

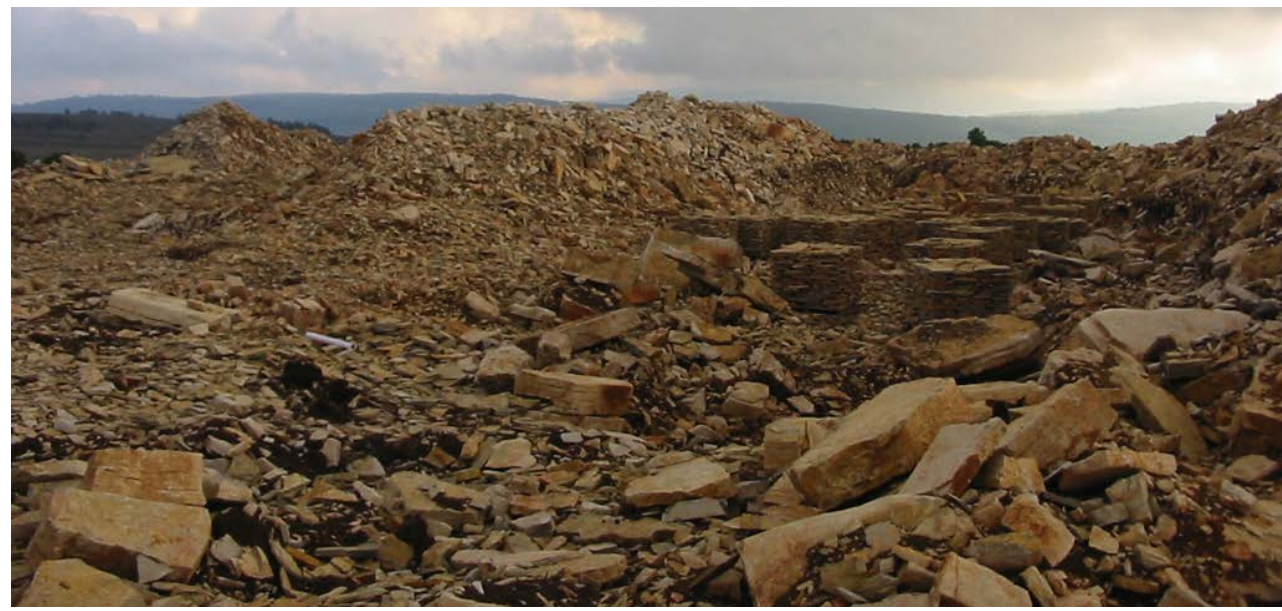

FOTOGRAFIA 1.Un aspecte dels materials extrets a la pedrera de llosses prop de Mosqueruela

Algepsl.2015 n.2 Recorregut de recerca geològica i mineralògica per les comarques de Gúdar - Javalambre i de I’Alcalatén: des de Mosqueruela a Puertomingalvo, Sant Joan de Penyagolososa i a Vistabella del Maestrat 


\subsection{Parada 3. Carretera a Linares de Mora i a Puertomingalvo, $\mathrm{km} 0$ ' 8 de la ruta A-1701, (terme municipal de Puertomingalvo, comarca de Gúdar - Javalambre). (Full 592).}

Després de fer l'aturada anterior, cal retornar a la carretera que enllaça Mosqueruela amb Mosqueruela amb Linares de Mora i amb Puertomingalvo la A - 1701. En arribar al Km 0’8 farem una nova aturada, a uns 0'2 $\mathrm{Km}$ de l'anterior.

En aquest recorregut hem anat trobant afloraments dels materials mesozoics esmentats a les aturades anteriors. Aquests materials, en bona part del recorregut, són eminentment carbonatats, d'edat cretàcica, situant-se com tot l'itinerari dintre del Sistema Ibèric. Aquests materials calcaris pertanyen al Cenomanià i són els que apareixen ara a l'indret de la present aturada.

En aquest lloc ens trobem davant d'un interessant poljé. Es tracta del conegut Poljé de Mosqueruela. És un dels Punts d'Interès Geològics d'Aragó mes coneguts. Es situa al llarg de més de $4 \mathrm{Km}$, tot seguint la carretera que procedeix de Mosqueruela, per on hem vingut. Així, la visió des d'aquest indret és immillorable.

Aquest indret, és un dels Punts d'Interès Geològic, catalogats al llibre de la DGA-DDAA (2001), sobre els LIG (Llocs d'Interès Geològic) aragonesos. (fotografia 2)

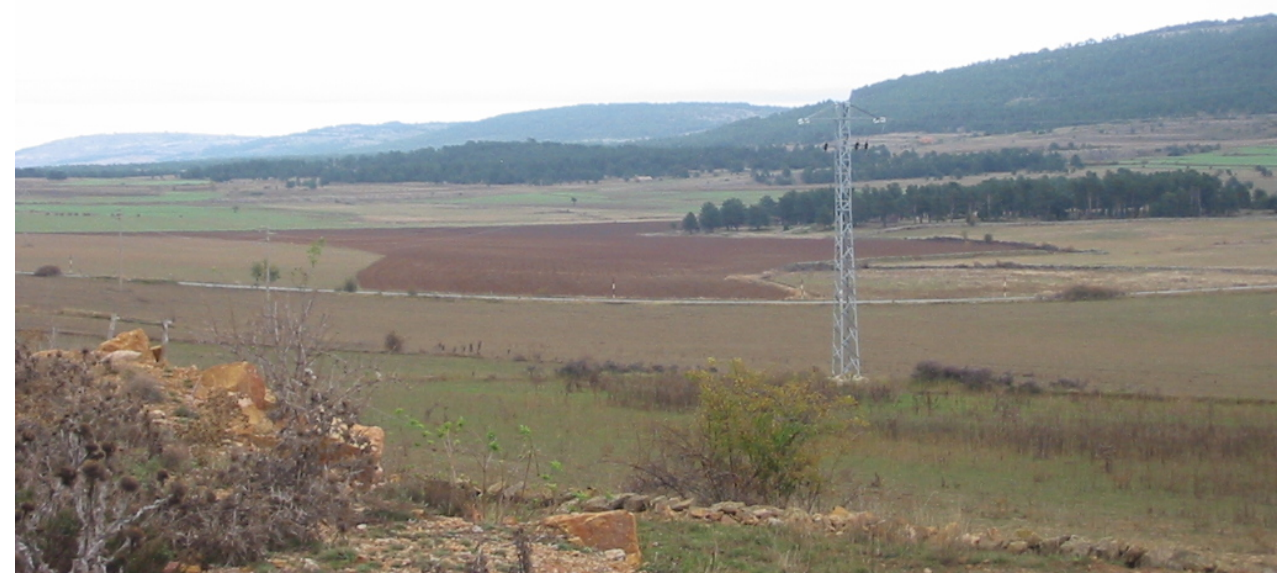

FOTOGRAFIA 2. Un ampli aspecte del Poljé de Mosqueruela

5.4. Parada 4. Carretera de Puertomingalvo a vVstabella del Maestrat, CV-170,

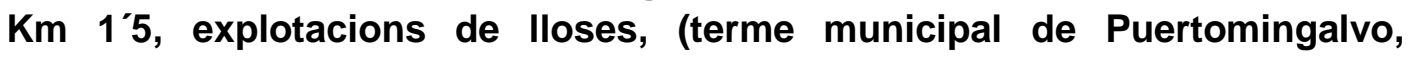
comarca de Gúdar - Javalambre). (Full 592). 
Després de realitzar la parada anterior, cal continuar per la carretera autonòmica aragonesa $\mathrm{A}$ - 1701, fins arribar a la propera cruïlla de carreteres. Aquí, ens caldrà seguir per la carretera valenciana CV - 175 (tot i ésser a l'Aragó, a la comarca de Gúdar - Javalambre). En agafar aquesta carretera ens caldrà anar cap al Sud, cap a Puertomingalvo. Tot i així, a uns 1'2 Km abans d'arribar-hi, trobarem la cruillla d'on surt la carretera valenciana CV - 170 (la qual condueix cap a Vistabella del Maestrat). Ens caldrà agafar-la. A uns 1'5 Km d'haver-la agafat, realitzarem la primera aturada a la vora de la carretera, a uns $10 \mathrm{Km}$ de la població anteriorment esmentada.

En aquest recorregut haurem anat trobant els materials mesozoics del Cretàcic (amb trams de calcolutítics i calcaris). Aquests materials formen part de les estructures del Sistema Ibèric. Aquests materials pertanyen la majoria de les vegades al Cenomanià; tot i que també hem trobat afloraments de les argiles i de les sorres de l'Albià

Aquí hi ha una explotació dels materials carbonatats del Cretàcic del Cenomanià. Aquests materials han estat explotats per tal de dedicar-los per a l'extracció de lloses per a la construcció. Aquestes explotacions encara es troben a I'actualitat en actiu. (fotografia 3)

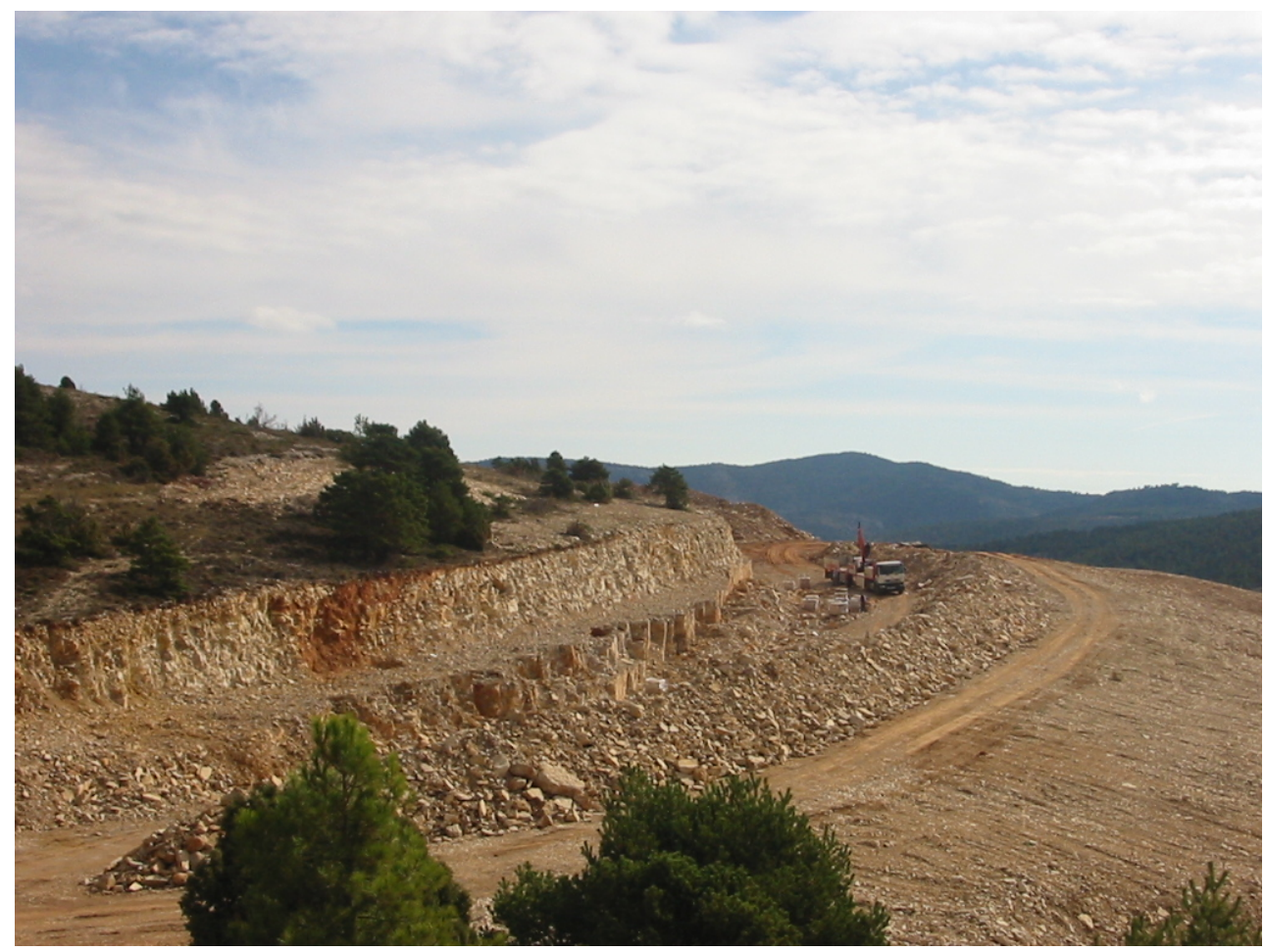

FOTOGRAFIA 3. Explotació de lloses, prop del Km 1'5 de la carretera CV-170

\subsection{Parada 5 - condicional. Carretera de Puertomingalvo a Vistabella del Maestrat, $\mathrm{Km} \mathrm{3’5}$, explotacions de lloses, (terme municipal de Puertomingalvo, comarca del Maestrazgo). (Full 592).}

Després de fer l'aturada anterior, cal continuar per la carretera que es dirigeix cap a Vistabella del Maestrat. A poc més de $2 \mathrm{Km}$ de la parada anterior, en caldrà fer-n'hi una altra, si s'escau,

Algepsl.2015 n.2 Recorregut de recerca geològica i mineralògica per les comarques de Gúdar - Javalambre i de I’Alcalatén: des de Mosqueruela a Puertomingalvo, Sant Joan de Penyagolososa i a Vistabella del Maestrat 
En aquest recorregut, haurem anat trobant els materials mesozoics a les aturades anteriors. Aquests materials, fonamentalment del Cretàcic, es troben situats dintre del Sistema Ibèric.

En aquest indret hi ha una explotació dels materials carbonatats del Cretàcic. Com a la parada anterior, aquests materials han estat explotats per tal de dedicar-los per a l'extracció de lloses per a la construcció. Aquestes explotacions encara es troben a l'actualitat en actiu. FOTOGRAFIA 4.

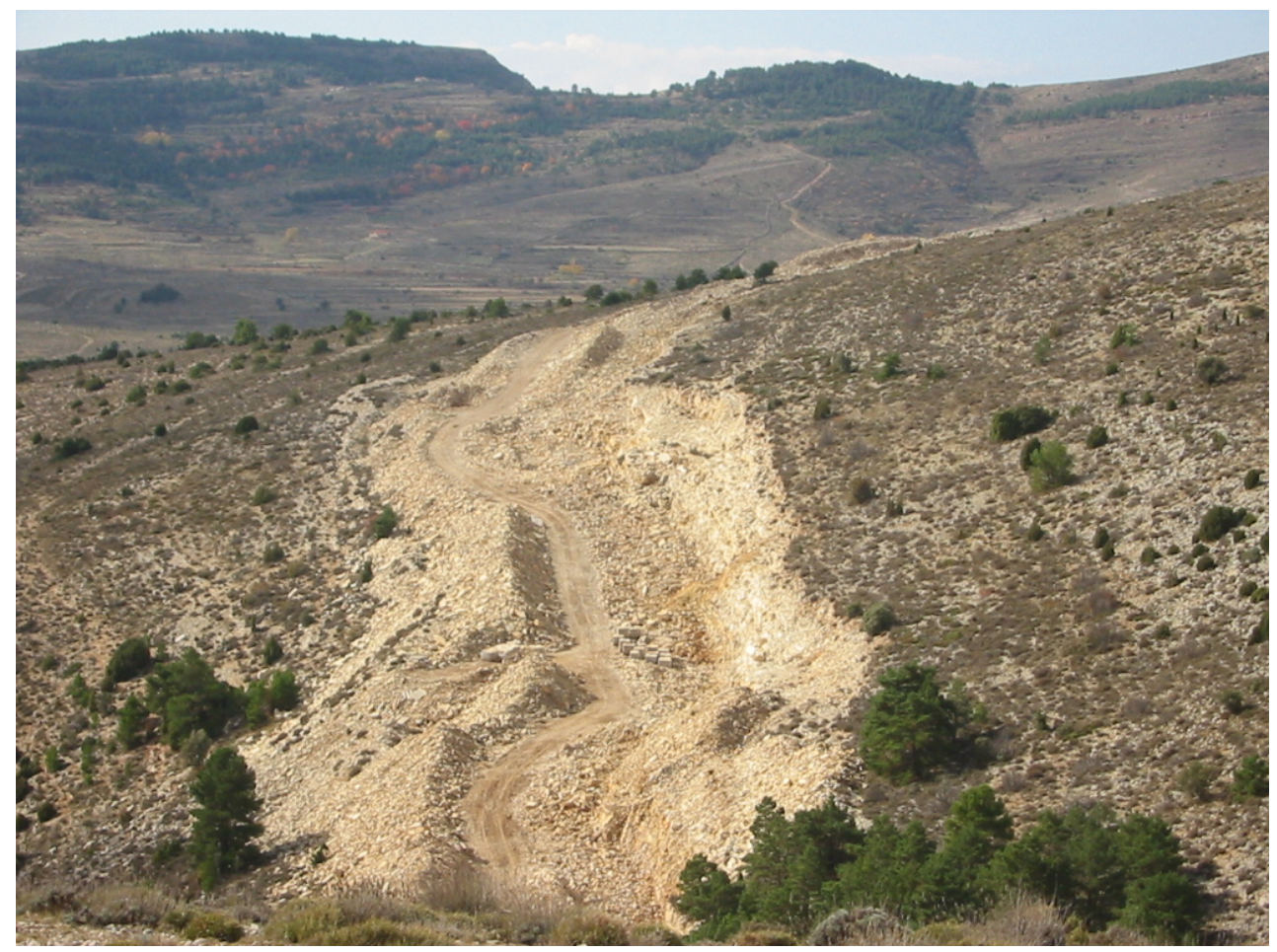

FOTOGRAFIA 4. Explotació de lloses, prop del Km 3’5 de la carretera CV - 170,

\subsection{Parada 6. Carretera de Puertomingalvo a Vistabella del Maestrat, CV-170, pont sobre el riu Montlleó. (termes municipals de Puertomingalvo, comarca de Gúdar - Javalambre, i de Vistabella del Maestrat, comarca de I’Alcalatén). (Full 592).}

Després de realitzar la parada anterior, cal continuar per la carretera autonòmica valenciana CV - 175 (que coincideix amb la carretera local VF - TE - 36), així, arribarem a l'indret on travessa per un pont, el riu Montlleó. En aquest indret, situat a uns $7-8 \mathrm{Km}$ des de la parada anterior, en farem una altra.

En aquest recorregut, hem continuat trobant afloraments dels materials carbonatats que hem esmentat als recorreguts cap a es aturades anteriors. Aquests materials, eminentment calcaris pertanyen al Cenomanià i es troben situats dintre del Sistema Ibèric, concretament dintre de la denominada Cuenca del Maestrazgo. També haurem trobat, ocasionalment, nivells de sorres i d'argiles cretàciques, de l'Albià. Tot i així, ara en aquest indret per on fem aquesta aturada, afloren els primers: els nivells calcaris cretàcics del Cenomanià. 
En aquest lloc, es pot veure el riu Montlleó, el qual procedeix de Puertomingalvo i que poc a poc es va encaixant cap a llevant. Aquí va encaixant-se poc a poc, entre les calcàries del Cenomanià. (fotografia 5)

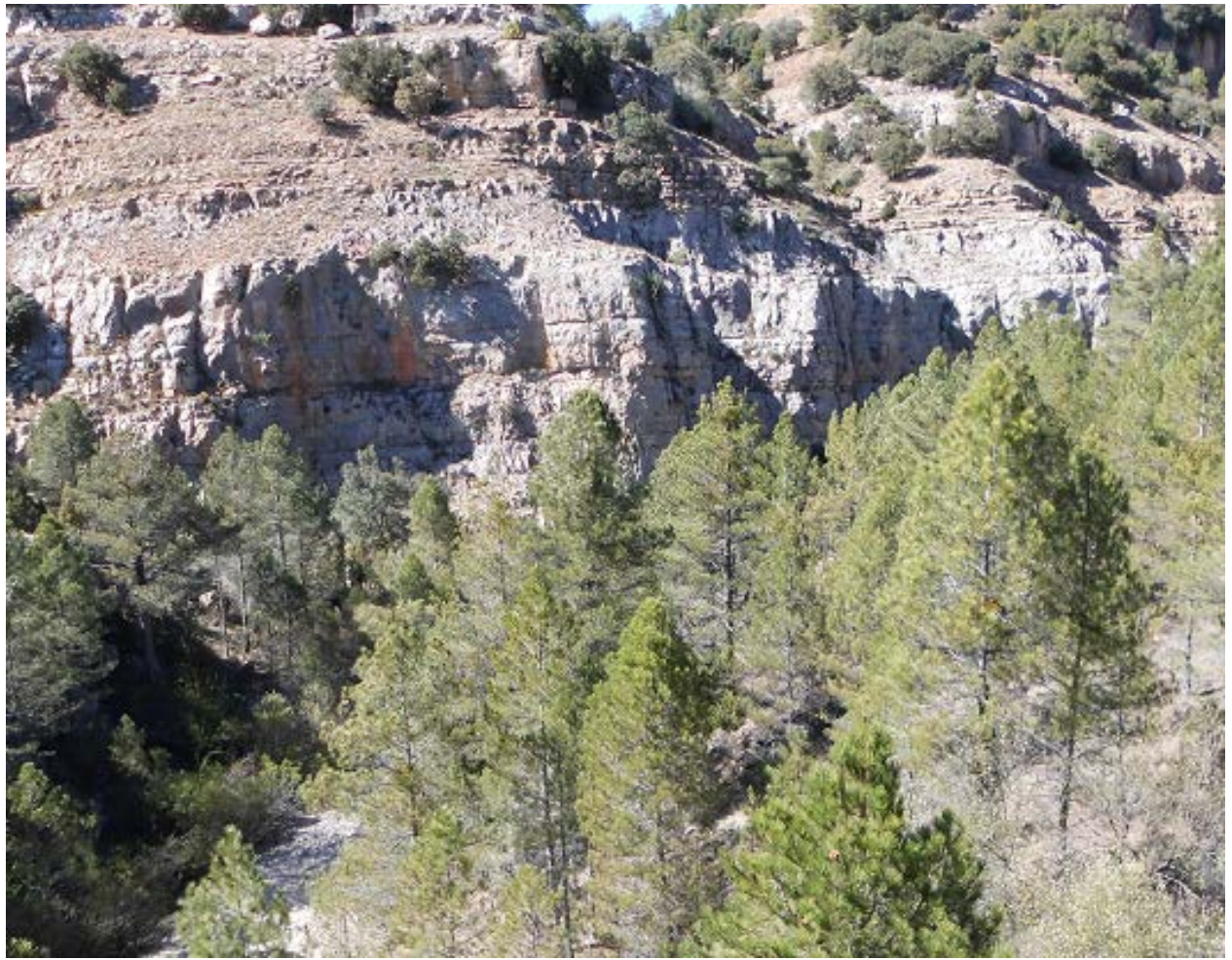

FOTOGRAFIA 5. El riu Montlleó, circulant entre les calcàries del Cenomanià

Finalment, cal dir que aquest riu, constitueix la frontera, a molts indrets, entre les comarques de Castelló i les comarques de Teruel, com en aquest indret, que separa la de Gúdar Javalambre (terme de Puertomingalvo) de la de l'Alcalatén (terme de Vistabella del Maestrat).

\subsection{Parada 7 - condicional. Cases de I'Alforí, (l'Alforí, terme municipal de Vistabella del Maestrat, comarca de l'Alcalatén). (Full 592).}

Des de la parada anterior, cal continuar per la carretera local que es dirigeix des de Puertomingalvo cap a Vistabella del Maestrat. Quasi en arribar a aquesta darrera, s'arribarà a una cruilla de quatre carreteres. Aquí, prop de les Cases de I'Alforí, es pot fer una nova aturada, aproximadament, a uns $10 \mathrm{Km}$, de la parada anterior.

En aquest recorregut, inicialment hem trobat afloraments dels materials esmentats a l'aturada anterior. Així, haurem vist afloraments de les calcàries i de les calcàries sorrenques que pertanyen majoritàriament al Cenomanià.

Tot i així, ben aviat, haurem començat a trobar afloraments dels materials del Pleistocè i de I'Holocè, amb graves, sorres i argiles. Aquests materials es situen al Poljé de Vistabella del Maestrat, que hem travessat.

Algepsl.2015 n.2 Recorregut de recerca geològica i mineralògica per les comarques de Gúdar - Javalambre i de I’Alcalatén: des de Mosqueruela a Puertomingalvo, Sant Joan de Penyagolososa i a Vistabella del Maestrat 
Des d'aquest indret, mirant cap al NW, cap al Nord i cap al NE, es pot veure part d'aquest extens poljé, un dels de màxima extensió de tota la Península Ibèrica. (fotografia 6)

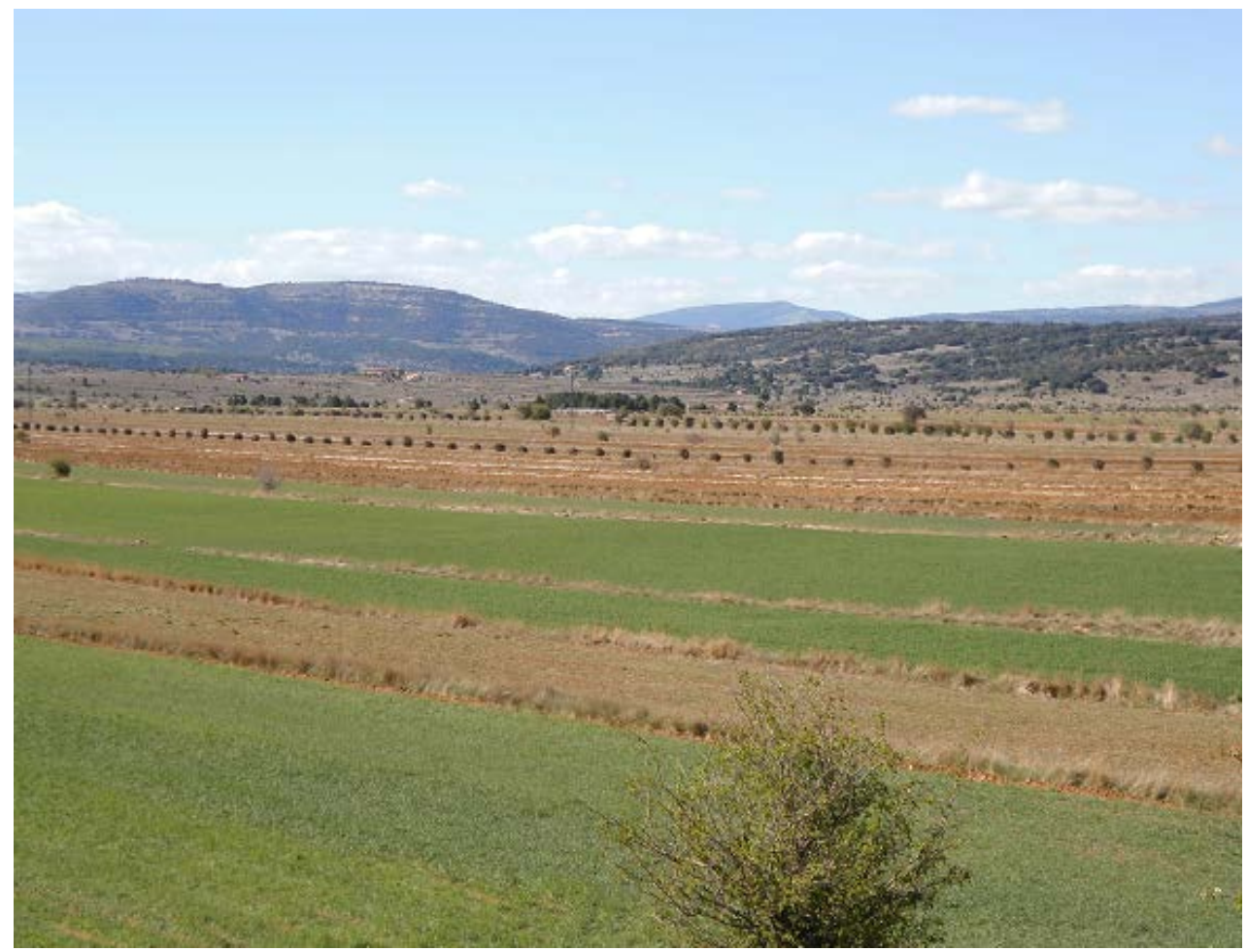

FOTOGRAFIA 6. El Poljé de Vistabella del Maestrat, des de I'Alforí

\subsection{Parada 8. Immediacions del santuari de Sant Joan de Penyagolosa, (Sant Joan de Penyagolosa, terme municipal de Vistabella del Maestrat, comarca de I’Alcalatén). (Full 592).}

Després de fer l'aturada anterior, cal continuar ara per la carretera que es dirigeix cap a ponent, cap al Santuari de Sant Joan del Penyagolosa, per on ens caldrà fer una nova aturada, en arribar-hi, a uns 6’5 Km des de la parada anterior, aproximadament.

En aquest recorregut, hem anat trobant afloraments dels nivells carbonatats del Cretàcic. Inicialment hem trobat les calcàries de l'Aptià, després nivells d'argiles i gresos de l'Albià i les calcàries del Cenomanià. Tot i així, bona part del recorregut I'hem fet entre els afloraments dels materials neògens, del Pleistocè i de l'Holocè, que reblen el Poljé de Vistabella del Maestrat, a través del qual hem circulat en diferents trams del recorregut.

També cal dir que en aquest recorregut, hem continuat gaudint de l'observació del poljé de Vistabella del Maestrat, el qual constitueix una plana de grans dimensions, de prop de $10-12$ Km de longitud.

Algepsl.2015 n.2 Recorregut de recerca geològica i mineralògica per les comarques de Gúdar - Javalambre i de I’Alcalatén: des de Mosqueruela a Puertomingalvo, Sant Joan de Penyagolososa i a Vistabella del Maestrat 


\subsection{Parada 9. Cim del Penyagolosa, (termes municipals de Vistabella del Maestrat i Xodos, de la comarca de I'Alcalatén; i terme municipal de Villahermosa del Río, de la comarca de l’Alt Millars). (Full 592).}

Des de la parada anterior, cal continuar per un camí que es dirigeix cap el Sud, per tal de continuar a peu des d'aquí, amb la intenció de pujar al cim del Penyagolosa, on farem una nova aturada d'aquest itinerari. Així, haurem efectuat un recorregut proper als $10 \mathrm{Km}$ des de la darrera aturada, però salvant un desnivell molt proper als 600 metres des de la parada anterior.

Com en els recorreguts anteriors, hem anat trobant afloraments dels materials carbonatats mesozoics (majoritàriament del Cretàcic). Aquests materials es troben dintre del Sistema Ibèric, que en aquest indret formen part del denominat "Muntanyam de Castelló". Precisament, en aquest Iloc es troba un aflorament dels nivells de calcàries, calcolutites i argil-lites. Aquests nivells pertanyen al cretàcic, i més concretament al Cretàcic Inferior, a l'Aptià. Aquests materials es troben constituint unes alternances, i donen Iloc a un interessant "relieve en Cuesta", visible des de la mateixa ciutat de Castelló. (fotografia 7)

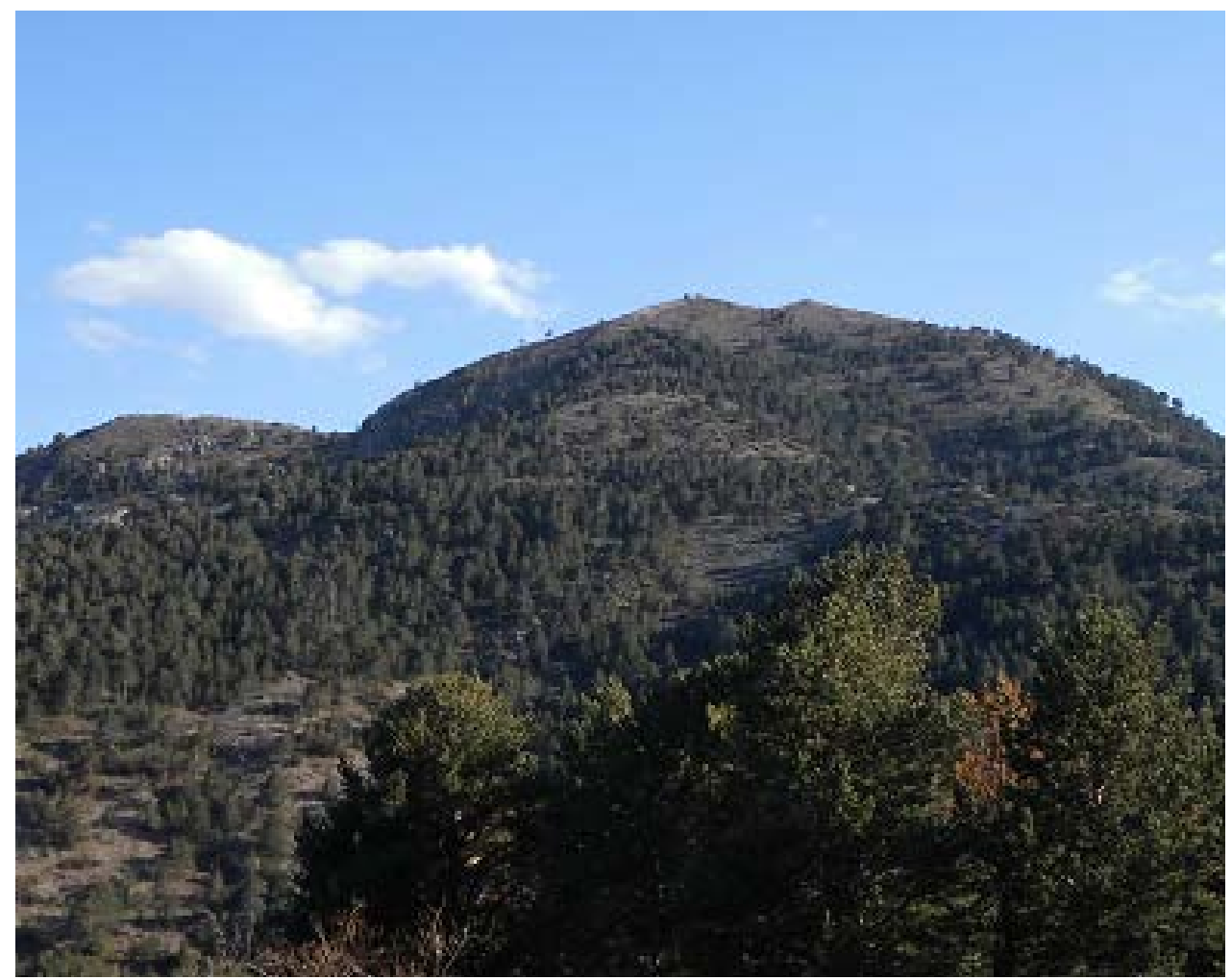

FOTOGRAFIA 7. Un aspecte del Penyagolosa, des de la Banyadera

Aquí, aquests materials constitueixen un dels cims més elevats del País Valencià (el Penyagolosa, de 1.813). Tot i així cal considerar que el com més elevat del País Valencià és el Calderó, el qual es troba situat a la comarca del Racó d'Ademús, en una zona fronterera amb Terol.

Algepsl.2015 n.2 Recorregut de recerca geològica i mineralògica per les comarques de Gúdar - Javalambre i de I’Alcalatén: des de Mosqueruela a Puertomingalvo, Sant Joan de Penyagolososa i a Vistabella del Maestrat 


\subsection{Parada 10. Immediacions del camp d'aviació, (terme municipal de Vistabella del Maestrat, comarca de I'Alcalatén). (Full 592).}

Després de fer l'aturada anterior, cal retrocedir cap al Santuari de Sant Joan de Penyagolosa, i després fins a l'indret on hem fet la PARADA 7 (prop de les Cases de l'Alforí). A partir d'aquí iniciarem una fillola cap al NNE, cap Camp d'Aviació. Després de sobrepassar l'esmentat camp, ens caldrà fer la primera aturada d'aquest itinerari, a uns $12 \mathrm{Km}$ de la parada anterior, a uns $8 \mathrm{Km}$ de Sant Joan de Penyagolosa.

En aquest recorregut, hem anat trobant afloraments dels materials mesozoics que constitueixen el Muntanyam de Castelló, del Sistema Ibèric Aquests materials són eminentment carbonatats, de caràcter calcari; pertanyen al Cretàcic Inferior. Precisament, tant la població de Vistabella com l'indret on ara ens trobem, es troba plenament situada sobre afloraments d'aquests materials mesozoics.

En aquest lloc, ens trobem al bell mig d'una extensa plana, de gairebé $10-12 \mathrm{Km}$ de llarg, entre la carretera de Joan de Penyagolosa i la que nosaltres hem anat seguint. Observant aquesta plana, es pot veure que es tracta d'un interessant poljé fent-se paleses diferents dolines i uwales, unes i altres recobertes superficialment per la denominada terra rossa, palesa per tot arreu. Aquesta terra és una excel-lent terra de conreu, i com a tal ha estat utilitzada per arreu pels camperols. (fotografia 8)

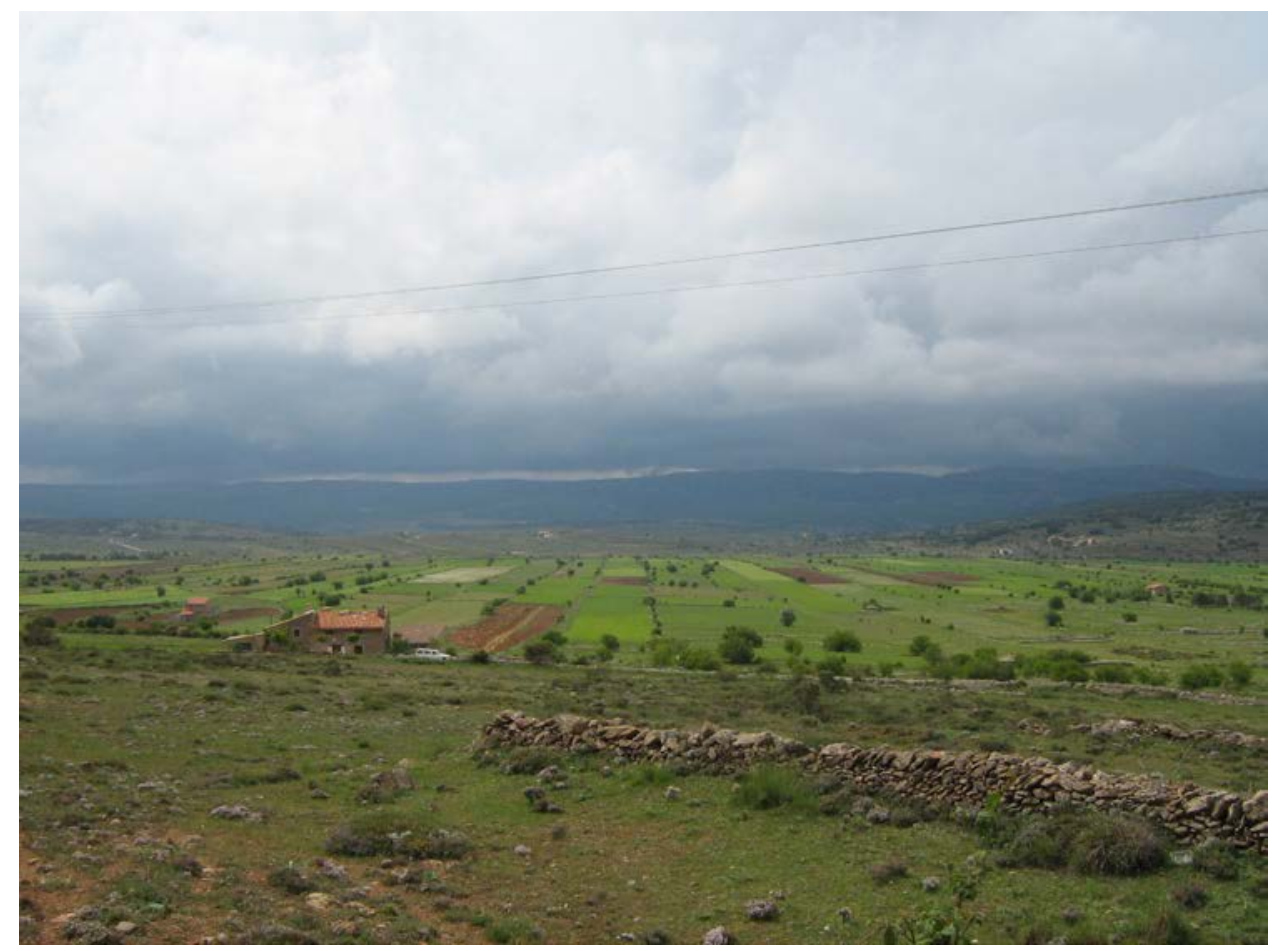

FOTOGRAFIA 8. Vista general del Poljé de Vistabella del Maestrat

\subsection{Parada 11 - condicional. El quinyo, (terme municipal de Vistabella del Maestrat, comarca de l'Alcalatén). (Full 592).}


Després de fer l'aturada anterior cal continuar cap al NNE, vorejant sempre el poljé que hem vist a la parada anterior. Aproximadament, a uns $2 \mathrm{Km}$ de l'indret anterior, caldrà fer una nova aturada si s'escau.

En aquest recorregut, hem continuat trobant els materials quaternaris ja esmentats a la parada anterior, els quals formen part del poljé, on estem ara situats. En aquest lloc, anomenat el Quinyo, després de diversos dies de pluja, pot arribar a acumular-se l'aigua, donant lloc a la formació d’embassament natural (i molt temporal) de l'aigua acumulada després de les pluges.

\subsection{Parada 12. El sumider, (terme municipal de Vistabella del Maestrat, comarca de l'Alcalatén). (Full 569).}

Després de fer l'aturada anterior cal continuar breument, uns 200 - 300 metres, anant cap el $\mathrm{NE}$, per tal d'arribar al paratge del Sumider. En aquest indret, molt proper a l'anterior, farem una nova aturada. Aquesta aturada la farem prop del Km 5.

En aquest breu recorregut, hem anat trobant els mateixos materials esmentats anteriorment, en el desplaçament cap el paratge del Quinyo. Pel que fa al sumider, es fa clarament palesa una fuita d'aigua. Es tracta de l'anomenat sumider del poljé. En aquest lloc, les aigües d'escorrentia, que circulen per entre els materials rogencs del poljé, arriben a un indret, on les aigües són captades per un colador (el sumider), passant així a tenir circulació subterrània. (fotografia 9)

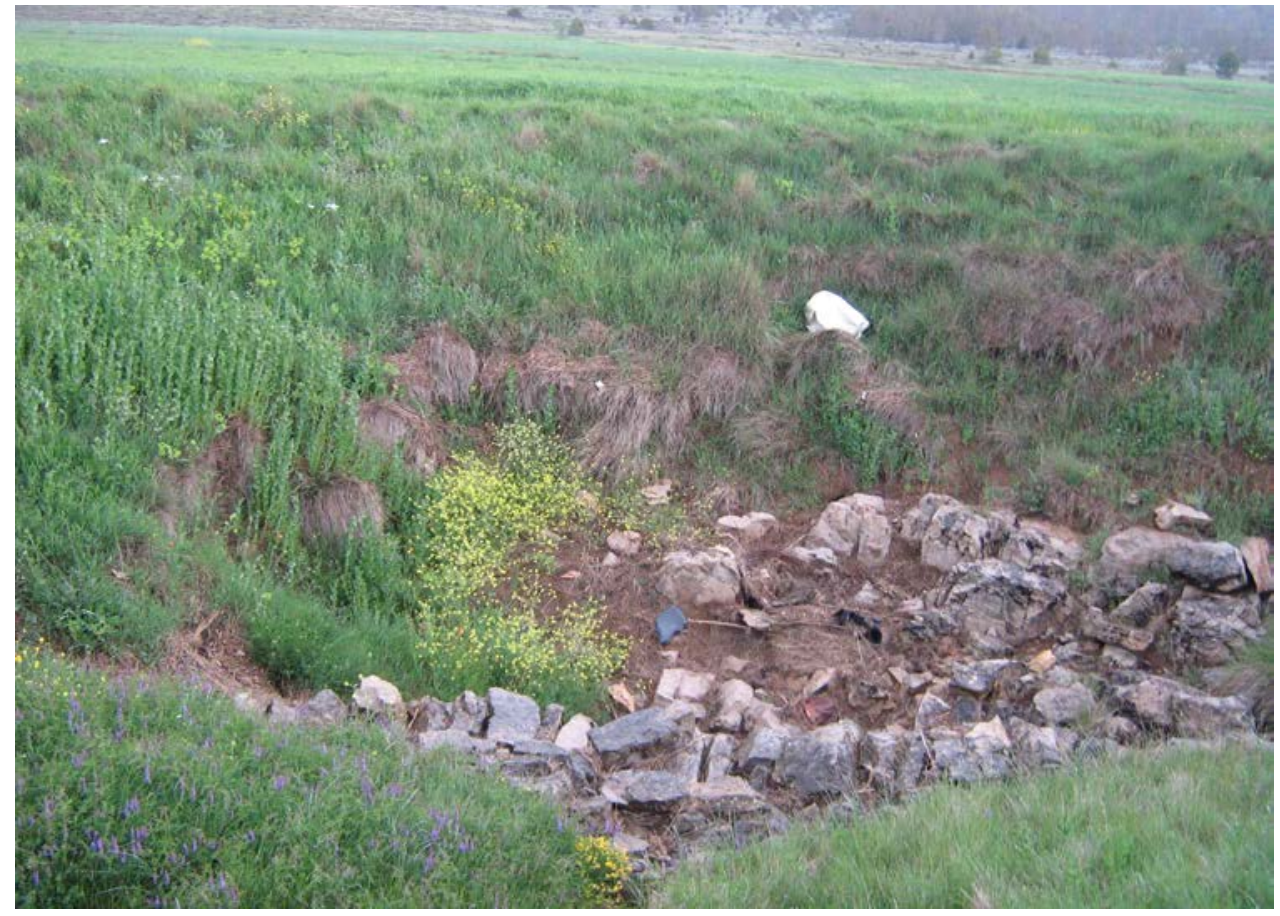

FOTOGRAFIA 9. El sumider del Poljé de Vistabella

Finalment, cal dir que més endavant aquestes aigües ressorgeixen a un indret que s'anomena los Ojals, prop del riu del Montlleó

Algepsl.2015 n.2 Recorregut de recerca geològica i mineralògica per les comarques de Gúdar - Javalambre i de l'Alcalatén: des de Mosqueruela a Puertomingalvo, Sant Joan de Penyagolososa i a Vistabella del Maestrat 


\subsection{Parada 13. Sortida de Vistabella del Maestrat, (terme municipal de Vistabella del Maestrat, comarca de I'Alcalatén). (Full 569).}

Després de fer l'aturada anterior cal retrocedir de nou cap a l'indret per on hem fet la PARADA 7 (prop de les Cases de l'Alforí). Després, des d'aquest indret, cal tornar a agafar la carretera CV - 170 (la que ens ha dut des de Puertomingalvo), per tal de continuar cap al proper poble de Vistabella del Maestrat. En arribar-hi, cal travessar-lo, per tal de fer la darrera aturada a la sortida de la població, tot anant cap a Atzeneta del Maestrat. Així, des de la parada anterior, haurem realitzat un desplaçament proper als $8 \mathrm{Km}$, per tal d'arribar fins aquí.

En aquest recorregut, hem anat trobant els materials esmentats a les aturades anteriors. Després, en apropar-nos a Vistabella, haurem trobat afloraments dels materials carbonatats del Cretàcic Inferior., de I'Aptià. Tots aquests materials es situen dintre del Sistema Ibèric, pels sectors anomenats Muntanyam de Castelló (RIBA et altri 1976).. Per d'altra banda, per aquest sectors de la serralada es fan paleses les interferències entre les "direccions catalanes" (NNE SSW) i les "direccions ibèriques" (WNW - ESE), amb un clar predomini de les segones.

Pel que fa la població de Vistabella del Maestrat, cal dir que efectivament aquesta es troba aturonada sobre els afloraments de les calcaries de I'Aptià; mentre que cap al SE, (per sota de la població, anant cap Atzeneta) s'observen afloraments dels materials del Juràssic. Cal dir que tots aquests materials són clarament visibles de l'indret per on fem aquesta darrera aturada.

En aquest indret finalitza el recorregut.

\subsection{Bibliografia emprada}

DGA-DDAA (2001).- Puntos de Interés Geológico de Aragón (Diversos Autores). Publicaciones de la Diputación General de Aragón. 242 pag. Zaragoza

FUSTER PUIG, P. (2014).- Vistabella del Maestrat entre Penyagolosa i el Montlleó. Mapa i Guia Excursionista a escala 1: 25.000. Terme Municipal de Vistabella del Maestrat. Tossal Cartografies. Castelló

GUIMERÀ, J. et altri (1992).- Geologia (II), Història Natural dels Països Catalans, Vol. 2, 547 pàg. Enciclopèdia Catalana, S.A.. Barcelona

IGME (1977).- Mapa Geológico de España a Escala 1:50.000 (Segunda Série-Plan Magna). Explicación de la hoja números: 569 (Mosqueruela). Inst. Geol. Min. España. Ministerio de Industria. Madrid

IGME (1986).- Mapa Geológico de España a Escala 1:200.000. Explicación de la hoja número: 48 / 5-6 (Vinaròs). Inst. Geol. Min. España. Ministerio de Industria. Madrid

MATA-PERELLÓ, J.M. (1991).- Inventari de Mineralitzacions i de Minerals del País Valencià. Col•lecció Informe, 546 pag. Manresa

Algepsl.2015 n.2 Recorregut de recerca geològica i mineralògica per les comarques de Gúdar - Javalambre i de l'Alcalatén: des de Mosqueruela a Puertomingalvo, Sant Joan de Penyagolososa i a Vistabella del Maestrat 
MATA-PERELLÓ, J.M. (1992).- Síntesi General de les Mineralitzacions de la Regió de Castelló, revista Algeps, $\mathrm{n}^{\circ}$. 7, 35 pàg. Manresa

MATA-PERELLÓ, J.M. (1995).- Apunts per a un itinerari geològic - mineralògic entre Llucena i el Penyagolosa (Alcalatén). Inèdit, 4 pag, Manresa

MATA-PERELLÓ, J.M. (2002).- Recorregut de recerca geològica per les comarques de I'Alcalatén i de l'Alt Millars: des de Llucena a Villahermosa del Río i al Penyagolosa. Xaragall, $n^{\circ} 177,10$ pag, Manresa

MATA - PERELLÓ, J. M. (2003).- Recorregut de recerca geològica per les comarques de I'Alcalatén, de l'Alt Millars i del Maestrazgo: des de Llucena a Villahermosa del Río, i des de Puertomingalvo al Penyagolosa, Inèdit, 11 pag. Manresa

MATA-PERELLÓ, J.M. (2014a).- Recorregut de recerca geològica per les comarques de l'Alt Millars i de Gúdar - Javalambre: des del Castillo de Villamalefa a Sucaina, Villahermosa del Río a Puertomingalvo i a Mosqueruela. Inèdit. 10 pàgines. Manresa

MATA-PERELLÓ, J.M. (2014b).- Recorregut de recerca geològica i mineralògica per la comarca de l'Alcalatén: des de Llucena a les Useres, Atzeneta a Vistabella del Maestrat. Inèdit. 12 pàgines. Manresa

MATA-PERELLÓ, J.M. i MONTANÉ GARCÍA, P. (2004).- Recorregut de recerca geològica i mineralògica per les comarques de la Plana Alta, l'Alcalatén i l'Alt Maestrat: des de la Vall d’Alba i Atzeneta a Vistabella del Maestrat i a Vilafranca del Cid. Inèdit, 13 pag. Manresa

MATA-PERELLÓ, J.M. i VILALTELLA FARRÀS, J. (2005a).- Recorregut de recerca geològica per les comarques del Maestrazgo i de I'Alt Maestrat: des de Puertomingalvo a Mosqueruela i a Vilafranca del Cid. Inèdit. 10 pàgines. Manresa

MATA-PERELLÓ, J.M. i VILALTELLA FARRÀS, J. (2005b).- Recorregut de recerca geològica per les comarques de l'Alt Millars i del Maestrazgo: des de Cedraman a Villahermosa del Río, i des de Puertomingalvo a Vistabella. Inèdit. 10 pàgines. Manresa

MATA-PERELLÓ, J.M. i VILALTELLA FARRÀS, J. (2014).- Recorregut de recerca geològica per les comarques de I'Alcalatén i de Gúdar - Javalambre: des de Vistabella del Maestrat a Puertomingalvo. Inèdit. 8 pàgines. Manresa

RIBA ARDERIU, O. et altri (1976).- Geografia Física dels Països Catalans. Edit. Ketres, 205 pàg. Barcelona. 